\title{
Does Information Overload of Annual Reports Matter?
}

\author{
Tze San Ong ${ }^{1}$, Boon Heng $\mathrm{Teh}^{2}$, Kai Cing Seng ${ }^{1} \&$ Sin Huei $\mathrm{Ng}^{3}$ \\ ${ }^{1}$ Faculty of Economics and Management, Universiti Putra Malaysia, Serdang, Malaysia \\ ${ }^{2}$ Faculty of Management, Multimedia University, Cyberjaya, Malaysia \\ ${ }^{3}$ Faculty of Economics and Management, Xiamen University Malaysia, Sepang, Malaysia \\ Correspondence: Tze San Ong, Faculty of Economics and Management, Universiti Putra Malaysia, Serdang, \\ Malaysia.
}

Received: October 22, 2019

Accepted: January 7, 2020

Online Published: March 17, 2020

doi:10.5430/ijfr.v11n2p243

URL: https://doi.org/10.5430/ijfr.v11n2p243

\begin{abstract}
Nowadays, information overload is an increasing concern and has become an alarming issue. Bursa Malaysia requires all PLCs to have corporate disclosures in their annual reports in order to cultivate good corporate governance. However, annual report readability issues are evident and poor annual report readability is a common occurrence in Malaysia. Thus, this paper seeks to empirically investigate the association between information overload issues, annual readability and financial performance of Malaysian PLCs. Secondary data consisting of 85 PLCs from the years 2015 to 2017 were used. The results have revealed that the information overload issues, i.e. too many disclosures for each company, negatively affect the companies' financial performance. Firms with annual reports that are easier to read with ideal readability have better financial performance. Not only that, fewer information overload issues tend to be encountered when the annual reports have good readability levels. Future studies are suggested to include primary data as well as non-listed companies for comprehensive coverage and generalization. Policy makers are encouraged to create minimum disclosure requirements which address the information gap between informed and uniformed investors. In addition, with developments in technology, advanced smartphone applications can be developed for investors to conveniently access the financial information of companies.
\end{abstract}

Keywords: information overload, annual reports, readability, financial performance, disclosures

\section{Introduction}

The Malaysian Accounting Standards Board (MASB) implements the Malaysian Private Entities Reporting Standards (MPERS) for private entities. For companies other than private entities, the Malaysian Financial Reporting Standards (MFRS) are implemented. Thus, MFRS is mostly applicable to publicly listed companies in Malaysia (MIA, 2012). Entities use effective accounting standards at the date of reporting as the basis for the preparation of financial statements. They are required to logically select appropriate accounting policies, with a full understanding of their implications on the financial statements. As early application is permitted, management can apply new accounting standards that have yet to be made effective.

Corporate disclosure is significant in the capital markets. As one of the communication tools between the managers and users, corporate disclosure is thought to have a dual nature comprising of mandatory disclosures and voluntary disclosures. Information overload has a great impact on information processing from preparers to user groups. Readability of information is an important consideration. From the quality of the disclosure to the readability of the users, many issues can arise as the readers attempt to understand the information. Thus, they believe that annual reports with more disclosures indicate more complex financial reporting systems. In the meantime, many users such as shareholders, investors and analysts are not able to get the information that they require; a lack of time hinders their understanding of large volumes of disclosures in financial reports.

According to Lee (1994) and Cooper et al. (1992), corporate annual reports merely present organizational images that differ from the 'true' story contained in the financial statements. Based on Dyball (1998), corporate annual reports can reflect and reproduce its consumerist culture. Accordingly, the financial information in the reports can be referenced to persuade consumers that the products of the organization are worth buying. A survey conducted by 
Deloitte UK (2000) found that the average length of a listed company's annual report was 56 pages but by 2010, this had increased to over 100 pages.

Based on their survey, PwC (2014) claimed that investors and other stakeholders may benefit from clear and understandable financial statement footnote disclosures when evaluating a company's performance and prospects for future cash flow. To address the issue of information overload, it is important to conduct research studies on it as there may be significant effects on the financial performance of the company. This study aims to determine the impact of annual report readability on the financial performance of Malaysian Public Listed Companies. Apart from that, it also intends to identify whether the disclosures in terms of mandatory or voluntary have effects on annual report readability.The objectives of this study are to investigate the relationship between information overload issues and the financial performance of Malaysian Public Listed Companies, to investigate the relationship between annual report readability and the financial performance of Malaysian Public Listed Companies, as well as to investigate the relationship between information overload issues and annual report readability. This study is a significant contribution to the existing body of research because it provides valuable information that can be utilized by investors, management, regulators and future researchers.

\section{Theoretical Foundations and Hypotheses Development}

In this study, three theories have been used to explain the effects of disclosures overload on company performance, namely the agency theory, legitimacy theory, and signaling theory.

Jensen \& Meckling (1976) described the agency theory as a relationship between one or more persons (the principals) and another person (the agent); these are the shareholder and the manager of a firm. The principals (shareholders) delegate agents (managers) with a certain amount of authority to manage the firm and make decisions on their behalf to ensure that their target returns are achievable. According to Armour et al. (2009), conflicts of interest exist between the corporate parties, i.e. insiders such as controlling shareholder and managers, and outsiders such as minority shareholder and creditors. These conflicts are referred to as 'agency problems'. There are two types of agency problems: a conflict between the owners of the firm (controlling shareholders) and the managers (Type 1 agency problem), as well as conflict between the owners of the firm (controlling shareholders) and the non-controlling shareholders (Type 2 agency problem).

Suchman (1995) defined legitimacy as "a generalized perception or assumption that the actions of an entity are desirable, proper, or appropriate within some socially constructed system of norms, values, beliefs, and definitions". Rouf (n.d.) described the legitimacy theory to assume the firms to be bounded with a social contract in which they need to perform the desired actions; this guarantees their continue existence. Magness (2006) also stated that the legitimacy theory portrays the idea of the social contract between the corporation and society. This theory also affirms that a firm has no right to continue with existence unless its norms or values match with society's expectations. Therefore, managers are required to disclose information that has the potential to change the opinion of external users (Cormier \& Gordon, 2001).

The signaling theory was essentially developed to clarify the case of information asymmetry (Spence 1973; Ross 1977). Omran and El-Galfy (2014) described this theory as useful when two parties such as individuals and organizations have access to different information. In this process, one party (the sender) must choose a mechanism to communicate the information or signal to another party (the receiver), who eventually chooses the method of interpreting the information or signal. Baiman and Verreccchia (1996) opined that the signaling theory encourages the disclosure of corporate information. The company has an interest in disclosing information as a signal to provide the market with additional information regarding the company, thus modifying investor expectations and reducing information asymmetries.

Kothari and Short (2003) stated that the review of corporate disclosures are mostly available from financial statements. These statements are prepared so that the managers can have a better understanding of the firm's financials through accrual estimates. In general, there are two forms of voluntary disclosure and mandatory disclosure. These are quantitative disclosure (direct financial information) and qualitative disclosure (narrative information). Merkley (2011) stated that many types of research have examined voluntary or quantitative disclosure, but there is a lack of research on the qualitative disclosures that interact with the performance information in mandatory reports from companies. One of the reasons behind this is that the current technology is not supported with the machine-readable format and such researches might incur higher costs to study the report. Merkley (2011) also claimed that prior research has only started to examine the importance of qualitative disclosure; it does not provide a full picture of the disclosures. 
Prior research has concluded that information overload or disclosures overload result in lower decision quality (Tuttle and Burton, 1999). KPMG (n.d.) also stated that the mandated disclosures and footnotes are the most significant source of disclosures overload and complexity. Apart from that, they identified materiality to be a contributor that increases the quantity of disclosures. Based on the agency theory, managers are acting in their own personal interests and thus, there are more unnecessary and complex disclosures. Conversely, managers acting in the interests of shareholders result in the reduction of unnecessary disclosures or complexities. Li (2008) stated that the Securities and Exchange Commission (SEC) has attempted to make the listed companies' prospectuses more reliable and understandable to the relevant users.

\subsection{Hypothesis Development}

According to Ranvinder and Anitha (2013), financial performance refers to the initiative to perform a financial activity or a degree to which financial objectives are being or have been achieved. It is the process of evaluating the results of a firm's policies and operations in monetary terms. Investors are interested in examining the performance of a company in comparison with other companies over time. When evaluating a company, one may be interested in the pattern of net income - whether it is increasing or decreasing (Maneje, 2012).

More disclosures in annual reports may increase the cost of preparing the annual report as well as confuse the investors and eventually affect their investment decision. Disclosures overload may result in a lack of time and energy from the investor to evaluate the extensive information regarding to current or potential investments of the company. Therefore, the quality of the decision may be poor and this will affect the firm's financial performance. Other than that, the high costs incurred by preparing the annual report may diminish earnings or lead to poor financial performance. Unnecessary and immaterial details can be potentially confusing to individual investors; it may limit their processing of material financial information (Deaves et al. 2006) and influence their decision making on investments. Based on the agency theory, information overload relates to the needs to explain the causes of the underperformed companeis. These companies are requred to justify the low performance wih their stakeholders.

Based on the above, the proposed hypothesis of this study is:

$\mathrm{H}_{1}$ : Information overload issues are negatively associated with a firm's financial performance.

In addition, the poor readability of the annual report may mislead the investor's understanding on the current and future prospects of a company. Thus, this may influence investment decisions and cause the company poor financial performance. $\mathrm{Li}$ (2008) concluded that there is a negative relationship between a firm's financial performance and its annual report's level of complexity such as the readability and length of the annual report. Furthermore, she also found that annual report readability is related to earning persistence. Firms with lower earning persistence are more likely to have more complicated annual reports when they are profitable. As less readable communication is hard to interpret, the investors require more time to extract the relevant information before decision making (Bloomfield, 2002). Thus, this study has formulated the following hypothesis:

$\mathrm{H}_{2}$ : Annual report readability is negatively associated with a firm's financial performance.

Annual reports of excessive lengths are a serious barrier that prevent individual investors from understanding the relevant information contained in financial disclosures. As disclosures increase (decrease), the readability of the annual report in terms of readability for index or report length might be higher (lower). More disclosures might lead to disclosure overload issues. Therefore, the investors may face difficulties in understanding the annual report. Lawrance (2013) stated that the form of disclosure is very significant as it can affect the readability of annual reports and the accuracy of information processed by the investors. SEC (2015) argued that legalistic or too complex presentations that make the most of the disclosures are difficult to understand. Disclosures that are clear and understandable can better reach and inform investors on the content, intent, and purpose of the annual reports. Hence, the next developed hypothesis is as follows:

$\mathrm{H}_{3}$ : Information overload issues are positively associated with annual report readability.

In this study, the control variable is firm size. According to Dosi et al. (1995), Jovanovic (1982), Palepu (1985) and Choi and Russell (2005), there is a strong relationship between firm size and firm growth. In addition, both are impacted by diversification in the performance of the firm as market diversification is an effective corporate strategy to grow and reduce market-related risk. 


\section{Methodology}

\subsection{Target Sample}

In this study, the target population consists of publicly listed companies in Malaysia. Bursa Malaysia is an exchange holding company which is approved under Section 15 of the Capital Markets and Service Act 2007. It provides a full range of exchange-related services such as trading, clearing, settlement and depository services. Bursa Malaysia is actively involved in the stock market activities. In addition, Malaysia has a diverse economy consisting of several types of industries such as oil and gas, construction, plantation, industrial and technology.

As Bursa Malaysia is the only listing board in Malaysia, the target population includes the publicly listed companies in Bursa Malaysia. Moreover, the companies which can be listed in Bursa Malaysia must fulfill certain requirements under the Securities Commission Malaysia (SC) Equity Guidelines and Bursa Malaysia's listing requirements. Hence, the annual reports of the publicly listed companies that are available in Bursa Malaysia can be reliably used as research data in this study. The sample was selected from the top 100 listed companies with full 3 years data without including the financial sectors. Financial sectors were excluded due to the different reporting requirement. After the screening process, a final of 85 listed companies on Bursa Malaysia was determined, where 15 companies were found to have missing data for the study periods. Secondary data was collected from 3 years of company financial reports from 2015-2017 on Bursa Malaysia. In addition, IBM SPSS Statistics Version 22 software and STATA software was used to conduct data screening to ensure that the obtained data is complete and accurate.

\subsection{Operationalization of Variables}

To measure the impact of company financial performance on investor decision, Earnings per Share (EPS) and Return on Assets (ROA) are the best methods of performance measurement. Thus, EPS and ROA were directly acquired from the companies' annual reports by using the formulas as shown below:

$$
\begin{gathered}
\text { Earnings per Share }(E P S)=\frac{\text { Net profit }}{\text { Number of Shares }} \\
\text { Return on Assets }(R O A)=\frac{\text { Net profit }}{\text { Total Assets }}
\end{gathered}
$$

To assess the readability of the annual reports, Gunning's Fog Index/ Readability Fog Index developed by Gunning (1952) with focus on text passage complexity as a function of syllables per words and words per sentence was adopted. The index shows the duration taken by a reader of average intelligence to read and understand the text. The formula for calculation is as below:

Fog $=($ words per sentence + percent of complex words $) * 0.4$

Other than that, report length was also used as proxy to determine the annual report readability. Report length refers to the number of pages in an annual report. The document length is more likely to be correlated with the number of disclosures $(\mathrm{Li}, 2008)$. In order to measure the length of the report, the natural logarithm of the number of words in an annual report is applied. The formula is as follows:

$$
\text { Length }=\log (\text { NWords })
$$

Where NWords is the number of words in the annual report

To determine information overload issues, a self-constructed disclosure checklist which included mandatory and voluntary disclosures were developed from the disclosure checklist prepared by PricewaterhouseCoopers (2009) and Albawwat et al. (2015). The disclosure items were checked against the financial reports from the companies. The disclosure checklist was prepared to ensure that the checklist items conformed with the IFRS disclosure requirements. The unweighted disclosure index was used. An item was scored one if disclosed, zero if not disclosed or not applicable if the item was not relevant to the company. The disclosure index was computed as:

$$
I x=\frac{T t x}{n x}
$$

Where,

$\mathrm{Ix}=$ the index scored by company $\mathrm{x}, 0 \leq \mathrm{Ix} \leq 1$

$\mathrm{Ttx}=$ the information item disclosed by company $\mathrm{x}$ 
$\mathrm{nx}=$ the maximum number of items expected to be disclosed by a company

In this study, the two regression models were adopted as follows:

Multiple Regressions

Model 1: FP $=\alpha+\beta$ VDI $+\beta$ MDI $+\beta$ READ $+\varepsilon$

Model 2: READ $=\alpha+\beta$ VDI $+\beta$ MDI $+\varepsilon$

Where, $\alpha$ : Intercept

$\beta$ : Regression coefficient

$\varepsilon$ : Error Term

VDI: Voluntary Disclosures Index

MDI: Mandatory Disclosures Index

READ: Annual Report Readability [(i.e. Readability Fog Index (RFI) and Report Length (LENGTH)]

FP: Financial Performance [i.e. Return On Assets (ROA) and Earning per Share (EPS)]

\section{Results and Discussion}

\section{Sample Companies Profiling}

Table 1. Sectors of sample companies

\begin{tabular}{lll}
\hline Sectors & Total & $\%$ \\
\hline Industrial Products & 24 & $28 \%$ \\
\hline Trading/Services & 20 & $24 \%$ \\
\hline Consumer Products & 18 & $21 \%$ \\
\hline Properties & 13 & $15 \%$ \\
\hline Others & 10 & $12 \%$ \\
\hline & 85 & $100 \%$ \\
\hline
\end{tabular}

As shown in Table 1, there are 24 Public Listed Companies (PLCs) under the category of industrial products sector among the 85 sampled PLCs. There are 20 PLCs under the trading/services sector while 18 PLCs fall under the consumer products sector. 13 PLCs fall under the properties category while the remaining 10 belong to other sectors such as finance, technology, construction, and telecommunication sectors. Table 2 Descriptive Statistics on Independent Variables, Dependent Variable, and Control Variable

Table 2. Descriptive statistics of the sample companies

\begin{tabular}{lllllll}
\hline Variables & Skewness & Kurtosis & Minimum & Maximum & Mean & Std. Deviation \\
\hline SOFP & 0.122 & 0.031 & 0.3333 & 0.8148 & 0.5704 & 0.08637 \\
\hline BCAD & 1.868 & 2.022 & 0 & 1 & 0.1549 & 0.32075 \\
\hline FI & 1.605 & 0.579 & 0.625 & 0.75 & 0.6485 & 0.04896 \\
\hline SOPO & 0.033 & -0.916 & 0 & 1 & 0.4392 & 0.29133 \\
\hline RFI & -0.635 & 3.400 & 13.6 & 21.4 & 18.1137 & 0.93624 \\
\hline LENGTH & -0.218 & 2.329 & 3.846 & 4.833 & 4.4588 & 0.13802 \\
\hline EPS & 1.242 & 6.335 & -74.03 & 110.89 & 11.0295 & 18.85268 \\
\hline
\end{tabular}




\begin{tabular}{lllllll}
\hline ROA & 1.868 & 9.763 & -17.01 & 47.20 & 4.2636 & 7.29342 \\
\hline FSIZE & -0.116 & -1.279 & 4.44 & 9.27 & 7.17 & 1.218 \\
\hline
\end{tabular}

Note: SOFP=Statement of Financial Position; BCAD = Business Combination and Disposals; FI = Financial Instruments; and SOPO = Social Policy; RFI= Readability Fog Index; Length= Length; EPS= Earnings per Share; ROA= Return on Assets; FSIZE= Firm Size

Table 2 indicates the descriptive statistics on all the variables of the study and the normality test. Mean values range from 0.4392 (SOPO) to 18.1137 (RFI). Skewness and Kurtosis values indicate that the data is normally distributed.

Table 3. Characteristics independent variables for models 1 and 2 (mandatory and voluntary disclosures) of sample companies

\begin{tabular}{|c|c|c|c|c|c|c|c|}
\hline & \multicolumn{7}{|c|}{ Range of Disclosure Scores } \\
\hline & & \multicolumn{2}{|c|}{2015} & \multicolumn{2}{|c|}{2016} & \multicolumn{2}{|c|}{2017} \\
\hline & & $\mathrm{N}$ & $\%$ & $\mathrm{~N}$ & $\%$ & $\mathrm{~N}$ & $\%$ \\
\hline \multirow[t]{4}{*}{ SOFP $(\%)$} & $76-100$ & 1 & $1 \%$ & 3 & $4 \%$ & 1 & $1 \%$ \\
\hline & $51-75$ & 66 & $78 \%$ & 82 & $96 \%$ & 84 & $99 \%$ \\
\hline & $26-50$ & 18 & $21 \%$ & 0 & $0 \%$ & 0 & $0 \%$ \\
\hline & $0-25$ & 0 & $0 \%$ & 0 & $0 \%$ & 0 & $0 \%$ \\
\hline \multirow[t]{4}{*}{$\mathrm{BCAD}(\%)$} & $76-100$ & 8 & $9 \%$ & 8 & $9 \%$ & 9 & $11 \%$ \\
\hline & $51-75$ & 0 & $0 \%$ & 0 & $0 \%$ & 0 & $0 \%$ \\
\hline & $26-50$ & 7 & $8 \%$ & 11 & $13 \%$ & 11 & $13 \%$ \\
\hline & $0-25$ & 70 & $82 \%$ & 66 & $78 \%$ & 65 & $76 \%$ \\
\hline \multirow[t]{4}{*}{ FI $(\%)$} & $76-100$ & 0 & $0 \%$ & 0 & $0 \%$ & 0 & $0 \%$ \\
\hline & $51-75$ & 85 & $100 \%$ & 85 & $100 \%$ & 85 & $100 \%$ \\
\hline & $26-50$ & 0 & $0 \%$ & 0 & $0 \%$ & 0 & $0 \%$ \\
\hline & $0-25$ & 0 & $0 \%$ & 0 & $0 \%$ & 0 & $0 \%$ \\
\hline \multirow[t]{4}{*}{ SOPO (\%) } & $76-100$ & 5 & $6 \%$ & 5 & $6 \%$ & 5 & $6 \%$ \\
\hline & $51-75$ & 17 & $20 \%$ & 20 & $24 \%$ & 22 & $26 \%$ \\
\hline & $26-50$ & 26 & $31 \%$ & 27 & $32 \%$ & 22 & $26 \%$ \\
\hline & $0-25$ & 37 & $44 \%$ & 33 & $39 \%$ & 36 & $42 \%$ \\
\hline
\end{tabular}

Note: SOFP=Statement of Financial Position; BCAD = Business Combination and Disposals; FI = Financial Instruments; and SOPO = Social Policy

Table 3 shows the characteristics of the sample companies, categorized with Mandatory (MDI) and Voluntary Disclosures (VDI) as independent variables.

According to Table 3, only a few companies (less than $10 \%$ of 85 companies) disclosed all or more than $75 \%$ of mandatory disclosures for their Statement of Financial Position (SOFP) (out of 27 items) within the years 2015-2017. 
Conversely, most of the companies disclosed about 51\%-75\%. This indicates that not all the mandatory disclosures in SOFP are required to be disclosed by all companies since the operations for each company differs. On the other hand, less than $15 \%$ of 85 companies disclosed $76 \%$ - 100\% of mandatory disclosures in Business Combination and Disposals (BCAD) (out of 2 items) and most of the companies have not disclosed these disclosures at all. A few companies also disclosed 50\% of BCAD which consists of business combination and disposal. This shows that most of the companies have no transactions on business combinations and disposals throughout the three years, or that the companies only have business combination transactions and vice versa. Moreover, $100 \%$ or all the companies disclosed at least $51 \%$ of the mandatory disclosures for Financial Instruments (FI) (out of 8 items).

For Voluntary Disclosure, Social Policy (SOPO) is the only disclosure that has been chosen. There are four items in this disclosure. Throughout the three years, only 5 companies out of 85 companies have at least $75-100 \%$ of the disclosures. Most of the companies only disclosed $0-25 \%$ of the disclosures in their annual reports. This reveals that some companies choose to adhere to the voluntary disclosure even though it is not required by the law, regulations or standards.

Table 4. Summary of multiple regression analysis

\begin{tabular}{|c|c|c|c|c|}
\hline \multirow[t]{2}{*}{ Model } & \multicolumn{2}{|c|}{ Unstandardized Coefficients } & \multirow[t]{2}{*}{ t-value } & \multirow[t]{2}{*}{$\mathrm{p}$-value } \\
\hline & $\mathrm{B}$ & Std. Error & & \\
\hline
\end{tabular}

Model 1:

Information Overload Issues and Annual Report Readability with Financial Performance (EPS)

\begin{tabular}{|c|c|c|c|c|c|}
\hline \multirow[t]{8}{*}{ EPS } & (Constant) & -196.278 & 48.689 & -4.031 & $0.000 * *$ \\
\hline & SOFP & -17.045 & 15.264 & -1.117 & $0.265^{\mathrm{ns}}$ \\
\hline & BCAD & -6.408 & 3.799 & -1.687 & $0.093 *$ \\
\hline & FI & 35.477 & 24.617 & 1.441 & $0.151^{\mathrm{ns}}$ \\
\hline & SOPO & -6.967 & 4.418 & -1.577 & $0.116^{\mathrm{ns}}$ \\
\hline & RFI & -0.257 & 1.271 & -0.202 & $0.840^{\mathrm{ns}}$ \\
\hline & LENGTH & 47.203 & 9.943 & 4.747 & $0.000 * *$ \\
\hline & FSIZE & -1.079 & .969 & -1.113 & $0.267^{\mathrm{ns}}$ \\
\hline
\end{tabular}

$\mathrm{R}^{2}=0.122$

Adjusted $\mathrm{R}^{2}=0.097$

Information Overload Issues and Annual Report Readability with Financial Performance (ROA)

\begin{tabular}{|c|c|c|c|c|c|}
\hline \multirow[t]{4}{*}{ ROA } & (Constant) & -37.472 & 23.334 & -1.606 & $0.110^{\mathrm{ns}}$ \\
\hline & SOFP & -9.442 & 7.315 & -1.291 & $0.198^{\mathrm{ns}}$ \\
\hline & BCAD & -3.304 & 1.821 & -1.815 & $0.071 *$ \\
\hline & FI & 14.043 & 11.798 & 1.190 & $0.235^{\mathrm{ns}}$ \\
\hline
\end{tabular}




\begin{tabular}{llllll}
\hline & SOPO & -1.573 & 2.117 & -0.726 & $0.469^{\mathrm{ns}}$ \\
\cline { 2 - 6 } & RFI & -1.013 & 0.609 & -1.664 & $0.097^{*}$ \\
\cline { 2 - 5 } & LENGTH & 14.022 & 4.765 & 2.943 & $0.004^{* *}$ \\
\cline { 2 - 6 } & FSIZE & -0.743 & .464 & -1.601 & $0.111^{\mathrm{ns}}$ \\
\hline $\mathrm{R}^{2}=0.074$ & & & & & \\
\hline
\end{tabular}

Adjusted $\mathrm{R}^{2}=0.048$

Model 2:

Information Overload Issues with Annual Report Readability (Readability Fog Index)

\begin{tabular}{llllll}
\hline RFI & (Constant) & 21.089 & 0.909 & 23.188 & $0.000 * *$ \\
\cline { 2 - 5 } SOFP & -2.051 & 0.706 & -2.907 & $0.004^{* *}$ \\
\hline BCAD & -0.483 & 0.187 & -2.578 & $0.011^{* *}$ \\
\hline FI & -1.597 & 1.194 & -1.338 & $0.182^{\text {ns }}$ \\
\hline SOPO & -0.016 & 0.214 & -0.073 & $0.942^{\text {ns }}$ \\
\hline FSIZE & -0.096 & 0.048 & -2.014 & $0.045^{* *}$ \\
\hline
\end{tabular}

$\mathrm{R}^{2}=0.103$

Adjusted R2 $=0.084$

Information Overload Issues with Annual Report Readability (Report Length)

\begin{tabular}{cccccc}
\hline LENGTH & (Constant) & 3.861 & 0.116 & 33.214 & $0.000 * *$ \\
\hline & SOFP & 0.503 & 0.090 & 5.573 & $0.000 * *$ \\
\hline & BCAD & 0.007 & 0.024 & 0.272 & $0.786^{\mathrm{ns}}$ \\
\hline FI & 0.553 & 0.153 & 3.625 & $0.000 * *$ \\
\hline & SOPO & 0.110 & 0.027 & 4.036 & $0.000 * *$ \\
\hline $\mathrm{R}^{2}=0.325$ & FSIZE & -0.014 & 0.006 & -2.231 & $0.027^{* *}$ \\
\hline
\end{tabular}

Adjusted R2 $=0.312$

* represents $\mathrm{P}<0.10$ (significant); ** represents $\mathrm{P}<0.01$ (significant); ${ }^{\text {ns }}$ represents non-significant 
Table 4 presents the multiple regression analysis of the results from this study. It suggests that the adjusted $\mathrm{R}^{2}$ of EPS and ROA are 0.122 and 0.074 , respectively. This shows that only $12.2 \%$ and $7.4 \%$ of the dependent variables (EPS and ROA) can be jointly described by the independent variables in this study, which are Statement of Financial Position (SOFP), Business Combination and Disposals (BCAP) and Financial Instrument (FI) of Mandatory Disclosure and Social Policy (SOPO) of Voluntary Disclosure, Readability (READ) and Report Length (LENGTH). Therefore, the remaining $87.8 \%$ and $92.6 \%$ of the dependent variables can be explained by other variables since only selected variables are being used in this research.

On the contrary, the adjusted $\mathrm{R}^{2}$ of RFI and LENGTH are 0.084 and 0.312 which means that only $8.4 \%$ and $31.2 \%$ of the dependent variables (RFI and LENGTH) can be clearly explained by the independent variables such as SOFP, BCAD, FI and SOPO. Rather than the general outcome, this study aims to investigate the outcomes of the dependent variables as a result of specific independent variables.

\section{Discussion}

\subsection{Disclosure Overload Issues and Companies' Financial Performance}

H1: Information overload issues are negatively associated with a firm's financial performance.

In this study, the model on information overload issues and financial performance (H1) is partially supported when the company size is being controlled, except for the Statement of Financial Performance (SOFP), Financial Instrument (FI) of Mandatory Disclosures and Social Policy (SOPO) of Voluntary Disclosure. Hence, these imply that not all the independent variables (Mandatory and Voluntary Disclosures) have relationships with the dependent variables (EPS and ROA).

The BCAD is negatively related to the Financial Performance of EPS and also ROA. This shows similarly against the determined hypotheses. Based on past studies, information overload issues including Mandatory and Voluntary Disclosures may negatively relate to the firm's financial performance. Except for BCAD, the other variables are not significant enough to affect the independent variables since their significance level is $>0.1$. This is because the dependent variable is not used for forming the independent variables, EPS, and ROA, which should be directly formed by net profits, outstanding shares or total assets.

In short, financial performance is significantly influenced by the disclosures in the annual report. According to the agency theory, this could be due to the investor needing more financial information from the companies to make a wise investment decision. The more disclosures there are in an annual report, the poorer the resulting financial performance. Therefore, it is likely that the investors rely on these disclosures while making their investment decisions, thus affecting financial performance.

\subsection{Readability and Companies' Financial Performance}

$\mathrm{H} 2$ : Annual report readability is negatively associated with a firm's financial performance.

In this research, $\mathrm{H} 2$ assumes that the annual report readability and financial performance are negatively correlated. However, this hypothesis (H2) is supported with a controlled company size. Hence, this implies that not all independent variables (RFI and LENGTH) have relationships with the dependent variables (EPS and ROA). The data obtained for annual report readability is based on RFI and LENGTH. High RFI and long LENGTH indicates that the annual reports are complex and have adverse effects on the firm's financial performance.

As per the results shown, there are positive earnings if the annual reports are easier to read or if the RFI is low. Indeed, the results for the financial performance show a negative association between annual report readability and the financial performance of the firm. Low financial performance tends to have a high readability fog index because of the poor reader index in Malaysia, which is high according to Raman et al. (2012). The investors only make an investment decision when the readability fog index is low as that would be understandable to them. For example, the ideal readability of an annual report is within the range of 10-12. This is consistent with the hypothesis because unreadable annual reports may result in investors making wrong decisions, thus eventually affecting financial performance.

With regards to LENGTH, it is statistically significant to the firm's financial performance since the p-value is $<0.1$. However, the positive t-value shows that LENGTH is positively associated with the financial performance. This indicates that with longer reports, the financial performance is better. Therefore, a lengthy annual report may not influence the investors or stakeholders while making their investment decisions. Instead, according to Deloitte (2015), new and revised regulations in the annual reports may enable more confident decision making by the stakeholder. Hence, it improves the financial performance of the firm. 
In general, with a controlled company size, annual report readability has a significant relationship with financial performance, either in a positive or negative way.

\subsection{Disclosures Overload Issues and Readability}

H3: Information overload issues are positively associated with annual report readability.

In this research, a model of information overload issues and investor readability (H3) is supported when company size is being controlled. Information overload issues, such as mandatory and voluntary disclosures, are significant to RFI and LENGTH because the p-value is $<0.1$. As seen from the results, most of the disclosures such as SOFP and BCAD are significant to the RFI. Also, there is a negative association between information overload issues and RFI since all the t-values are negative. For LENGTH, the disclosures including SOFP, FI, and SOPO are significant since the $\mathrm{p}$-value is $<0.1$. Their t-values are positive, indicating that they are positively associated with annual report readability of LENGTH.

In short, the results for the relationship RFI is negatively associated with information overload issues. Thus, it does not align with the hypothesis. More disclosures do not negatively affect the readability fog index; disclosure overload may merely comply with the laws, regulations or accounting standards without deteriorating the annual report readability. However, more information or disclosures in annual reports tend to result in longer reports because information overload issues are mainly directly influenced by the report length. This indicates the positive relationship between information overload issues and annual report length.

\subsection{Implication of the Study}

From the management perspective, this study provides valuable information regarding disclosures in annual reports, which can be categorized into mandatory disclosures and voluntary disclosures. Other than that, the regulators may benefit from implementing the outcome of this study, which may aid the creation of minimum disclosure requirements as well as reduce the information gap between informed and uniformed investors.

Due to cutting edge technology available these days, advanced smartphone applications can be developed for the investors to conveniently access the annual reports or financial information of companies. This may improve readability for the investors since it is easier to obtain information through applications that are user friendly. It could include access to the annual reports and enable downloading of financial information via only one click.

\subsection{Limitations and Areas for Further Research}

In the first instance, secondary data is used in this research. Although there are some benefits to using secondary data, it has its own disadvantages. For instance, the quality of secondary data is an uncertainty. Therefore, there is a probability that the data may be recorded wrongly, resulting in inaccurate interpretations of the data. Moreover, this research only focused on the public listed companies from Bursa Malaysia as the target population to the detriment of the private or unlisted companies. Thus, bias is promoted with no basis for the generalization of the outcomes of the study. Furthermore, this study only emphasizes the direct relationship between disclosure overload issues and annual report readability. It does not involve intervening variables which are required to further enhance the evaluation of the extent of relationships between the variables in order to determine the direct, indirect and total effects.

In the future, it is suggested to use primary data instead of secondary data. For example, questionnaires can be distributed online or directly to the public with emphasis on investors or potential investors. Through this method, investor readability may be better determined. Apart from that, future researchers can include private companies as part of their target population, since the accounting policies or standards adopted by private companies may not necessarily differ from that of the public listed companies. This will produce more representative samples and generalized results.

Annual report readability may act as a mediator in an association between disclosure overload issues and financial performance since it has an indirect influence on both variables. Hence, future researchers may explore this area of research by using readability as the mediating variable.

\section{Conclusion}

The objectives of this study are to investigate the association between information overload issues and the financial performance of Malaysian Public Listed Companies, to investigate the association between annual report readability and the financial performance of Malaysian Public Listed Companies, and to investigate the association between information overload issues and annual report readability. 
The results suggest that not all independent variables (Mandatory and Voluntary Disclosures) have relationships with the dependent variables (EPS and ROA). Furthermore, low financial performance tends to have high readability fog index because of the poor reader index in Malaysia which is high. In general, with a controlled company size, annual report readability has a significant relationship with financial performance, either in a positive or negative way. However, more information or disclosures in annual reports tend to result in a longer report. Information overload issues are mainly and directly influenced by the report length which indicates a positive relationship between information overload issues and annual report length.

Nevertheless, policy makers or regulators may consider implementing minimum requirements to reduce the information gap between informed and uninformed investors. Thus, a set of principles can be identified to mitigate the complex information or disclosures and review whether there is duplication of existing disclosure requirements. Company management may also improve their company's disclosures by providing useful information in order to reduce information overload issues. Therefore, the report length may be shortened to assist the investors or stakeholders to make wise investment decisions.

In summary, the existence of the association between disclosure overload issues and readability with financial performance is supported. As a significant relationship has been proven in this study, management should improve their annual reports in terms of disclosures, length, and readability in order to aid investors in making the best investment decisions.

\section{References}

Albawwat, A. H., Basah, M. Y., \& Khairi, K. F. (2015). The Relationship between Voluntary Disclosure and Company Performances on Interim Reports in Jordan Using the Method of Causality Directions. International Journal of Economics and Finance IJEF, 7(7). https://doi.org/10.5539/ijef.v7n7p217

Armour, J., Hansmann, H., \& Kraakman, R. H. (2009, July 20). Agency Problems, Legal Strategies, and Enforcement. Oxford Legal Studies Research Paper No. 21/2009; Yale Law, Economics \& Public Policy Research Paper No. 388; Harvard Law and Economics Research Paper Series No. 644 ; European Corporate Governance Institute (ECGI) - Law Working Paper No. 135/2009. Retrieved from https://ssrn.com/abstract=1436555

Baiman, S., \& Verrecchia, R. E. (1996). The Relation Among Capital Markets, Financial Disclosure, Production Efficiency, and Insider Trading. Journal of Accounting Research, 34(1), 1. https://doi.org/10.2307/2491329

Bloomfield, R. J. (2002). The "Incomplete Revelation Hypothesis" and Financial Reporting. Accounting Horizons, 16(3), 233-243. https://doi.org/10.2308/acch.2002.16.3.233

Cooper, C., Pheby, D., Pheby, K., \& Puxty, A. (1992). Accounting Truth and Beauty. 15th Annual Congress of the European Accounting Association, Spain.

Cormier, D., \& Gordon, I. M. (2001). An examination of social and environmental reporting strategies. Accounting, Auditing \& Accountability Journal, 14(5), 587-617. https://doi.org/10.1108/EUM0000000006264

Deaves, R., Dine, C., \& Horton, W. (2006, May 24). How Are Investment Decisions Made? Task Force to Modernize Securities Legislation in Canada.

Deloitte UK: Average Length of 2010 Annual Reports Is 101 Pages. Only 44 Pages in 1996. (n.d.). Retrieved November

2016,

from http://www.big4.com/news/deloitte-uk-average-length-of-2010-annual-reports-is-101-pages-only-44-pages-in-1 996/

Disclosure Overload and Complexity: Hidden in Plain Sight - KPMG. (n.d.). Retrieved October 30, 2016, from http://www.bing.com/cr?IG=96D257F079524E49828BF82146A38AB9\&CID=054D0951408E6B8E1D5F008C 41BF6A38\&rd=1\&h=ovGjR6A4kMJX2v8Q6pO4Kn9oQhzGBLrLfFBqaSa78ro\&v=1\&r=http://www.kpmg.co $\mathrm{m} / \mathrm{US} / \mathrm{en} /$ IssuesAndInsights/ArticlesPublications/Documents/disclosure-overload-complexity.pdf\&p=DevEx,50 84.1

Dyball, M. C. (1998). Corporate Annual Reports as Promotional Tools: The Case of Australian National Industries Limited. Asian Review of Accounting, 6(2), 25-53. https://doi.org/10.1108/eb060696

Gunning, R. (1952). The technique of clear writing. New York, McGraw-Hill 
Healy, P. M., \& Palepu, K. G. (2001). Information asymmetry, corporate disclosure, and the capital markets: A review of the empirical disclosure literature. Journal of Accounting and Economics, 31(1-3), 405-440. https://doi.org/10.1016/S0165-4101(01)00018-0

Jensen, M. C., \& Meckling, W. H. (1976). Theory of the firm: Managerial behavior, agency costs and ownership structure. Journal of Financial Economics, 3(4), 305-360. https://doi.org/10.1016/0304-405X(76)90026-X

Kothari, S. P., \& Short, J. E. (2003). The Effect of Disclosures by Management, Analysts, and Financial Press on the Equity Cost of Capital.

Lawrence, A. (2013). Individual investors and financial disclosure. Journal of Accounting and Economics, 56(1), 130-147. https://doi.org/10.1016/j.jacceco.2013.05.001

Lee, T. (1994). The Changing Form of the Corporate Report. The Accounting Historians Journal, 21(1), 215-232. https://doi.org/10.2308/0148-4184.21.1.215

Li, F. (2008). Annual report readability, current earnings, and earnings persistence. Journal of Accounting and Economics, 45(2-3), 221-247. https://doi.org/10.1016/j.jacceco.2008.02.003

Magness, V. (2006). Strategic posture, financial performance and environmental disclosure. Accounting, Auditing \& Accountability Journal, 19(4), 540-563. https://doi.org/10.1108/09513570610679128

Menaje., P. M., Jr. (2012, September). Impact of Selected Financial Variables on Share Price of Publicly Listed Firms in the Philippines. American International Journal of Contemporary Research, 2(9).

Merkley, K. J. (2010, January). More than Numbers: R\&D-related Disclosure and Firm Performance.

Omran, M. A., \& El-Galfy, A. M. (2014). Theoretical perspectives on corporate disclosure: A critical evaluation and literature survey. Asian Review of Accounting, 22(3), 257-286. https://doi.org/10.1108/ARA-01-2014-0013

Ravinder, D. D., \& Anitha, M. (2013). Financial Analysis - A Study. IOSR Journal of Economics and Finance, 2(3), 10-22. https://doi.org/10.9790/5933-0231022

Rouf, A. (n.d.). Theoretical Framework of Corporate Voluntary Disclosure (CVD).

Spence, M. (1973). Job Market Signaling. The Quarterly Journal of Economics, 87(3), 355. https://doi.org/10.2307/1882010

Suchman, M. C. (1995). Managing Legitimacy: Strategic and Institutional Approaches. Academy of Management Review, 20(3), 571-610. https://doi.org/10.5465/amr.1995.9508080331

Tuttle, B., \& Burton, F. G. (1999). The effects of a modest incentive on information overload in an investment analysis task. Accounting, Organizations and Society, 24, 673-687. https://doi.org/10.1016/S0361-3682(99)00017-3 